\title{
On the occurrence of the wreckfish Polyprion americanus in the Gulf of Trieste (northern Adriatic Sea)
}

\author{
Nicola BETTOSO ${ }^{*}$, Lisa FARESI ${ }^{1}$, Alessandro FELLUGA ${ }^{1}$ and Lovrenc LIPEJ ${ }^{2}$ \\ ${ }^{1}$ ARPA FVG, Via A. La Marmora 13, 34139 Trieste, Italy \\ ${ }^{2}$ Marine Biology Station, National Institute of Biology, Fornače 41, 6330 Piran, Slovenia \\ *Corresponding author, e-mail: nicola.bettoso@arpa.fvg.it
}

\begin{abstract}
On 3rd June 2018 three juvenile specimens of Polyprion americanus were captured in the Gulf of Trieste. The wreckfish is a long-lived deep-water demersal species characterized by an extended pelagic juvenile phase. The juvenile forms are recurrently recorded in the northern Adriatic and due to data deficiency for this species, original morphometric data are shown. The occurrence of $\mathrm{P}$. americanus in the Gulf of Trieste is not a typical case of thermophilic species moving northward due to Mediterranean tropicalization, rather its recurrent appearance could be investigated for specific hydrological conditions coupled to its peculiar life span.
\end{abstract}

Key words: Polyprion americanus, morphometric data, pelagic phase, Gulf of Trieste, Adriatic Sea

\section{INTRODUCTION}

The wreckfish Polyprion americanus (Bloch $\&$ Schneider, 1801) (Pisces: Polyprionidae) is a panoceanic species that occurs in the southern Pacific, southern Australia, southern Indian Ocean and on both sides of the Atlantic Ocean, including Mediterranean, but excluding the tropics (BALL et al., 2000; MACHIAS et al., 2003). Genetic analysis distinguished three subpopulations among North Atlantic-Mediterranean, Brazil and South Pacific (SEDBERRY et al., 1999). Wreck fish is a long-lived deep-water demersal species, able to live up to 78 years of age (WAKEFIELD et al., 2013) and it is characterized by an extended pelagic juvenile phase associated with floating objects (SEDBERRY et al., 1999; BALL et al., 2000). Demersal adults inhabit rocky bottoms and muddy grounds at depths ranging from 40 to $800 \mathrm{~m}$, although it is more frequent in areas deeper than $300 \mathrm{~m}$ (KIRINČIĆ \& LEPETIĆ, 1955; BOMBACE, 1972; TORTONESE, 1975; FISCHER et al., 1987), whereas the maximum depth reported was 1,000 m (SEDBERRY et al., 1999).

Along the Italian coasts $P$. americanus is present in all the seas, excepting the Middle and the North Adriatic (TORTONESE, 1975; FISCHER et al., 1987). MARČETA (1999) mentioned this species in the list of the vertebrates of Slovenia, whereas in the Red book of Croatian marine fishes JARDAS et al. (2008) mentioned it as present mainly in the deep areas of the southern Adriatic and that juvenile specimens could be found also in northern areas such as the western coast of Istria. Due to the lack of data they evaluated this species as data deficient. The occurrence of adult stages has been reported off the north-western Sicily from Cape Milazzo to the Egadi Islands, on the rocky bottoms characterized by caves, crevices and by 
the deep coralligenous biocoenosis (BOMBACE, 1972). In the southern Sardinian Sea, its presence was observed between 500 and $720 \mathrm{~m}$ (CAU, 1980). Finally in the southern Adriatic KIRINČIĆ \& LEPETIĆ (1955) reported the capture of wreckfish from 400 to $700 \mathrm{~m}$, even on muddy bottoms, with a higher frequency between 500 and $600 \mathrm{~m}$. The presence of pelagic juveniles (10 $\mathrm{cm}$ length) was reported by LO BIANCO (1909) in summer (June) in the Gulf of Naples. KIRINČIĆ \& LEPETIĆ (1955) recorded these juveniles (20-25 $\mathrm{cm}$ length) along coastal waters in the eastern part of the southern Adriatic, associated with Naucrates ductor. Nevertheless the southern distribution of this species, juveniles pelagic forms are recurrently recorded and caught also in the Gulf of Trieste, the northernmost basin of the Adriatic Sea. The paper aims to report original morphometric data for this species and to discuss about its presence in this basin.

\section{MATERIAL AND METHODS}

On $3^{\text {rd }}$ June 2018 three specimens of $P$. americanus (Fig. 1) were captured by a leisure fisherman about $2 \mathrm{Nm}$ off Muggia (Gulf of Trieste), nearby the Italy-Slovenia maritime borderline. These specimens were cruising beneath the fisherman's boat, being a floating object, and they were easily caught by a baited fishing hook.

These were frozen and successively identified in laboratory as juvenile pelagic individuals of $P$. americanus. The following morphometric measurements were performed according to MACHIAS et al. (2003): total length (TL), standard length (SL), pre-anal length (PAL), pre-dorsal length (PDL), head length from the lower jaw (HL1), head length from the upper jaw (HL2), peduncle $(\mathrm{P})$, anal height $(\mathrm{AH})$, somatic height $(\mathrm{SH})$, head height $(\mathrm{HH})$, eye diameter $(\mathrm{E})$ and snout length (S). Isomorphism among specimens was tested by Pearson linear correlation coefficient (PCC). Furthermore, the specimens were weighed and the stomach content was analyzed under stereo microscope.

In the meantime (22 $2^{\text {th }}$ July 2018) another specimen was photographed off Poreč (western Istria) (Fig.2), whereas the previous documented

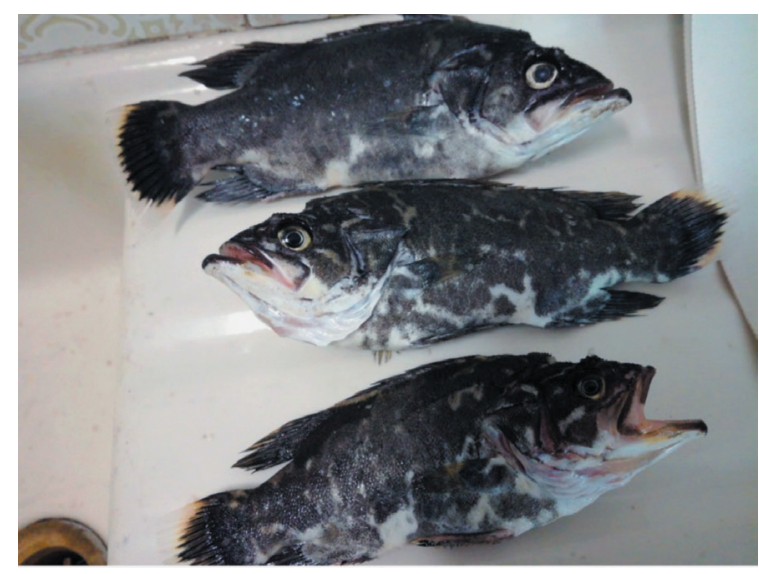

Fig. 1. Juveniles of Polyprion americanus caught in 2018 (Photo: A. Felluga)

records in the Gulf of Trieste arose to June 2009 (Fig. 3). Another specimen, which measured around $25 \mathrm{~cm}$ in total length, was caught in waters off Piran at $12^{\text {th }}$ July 2014 (Fig. 4).

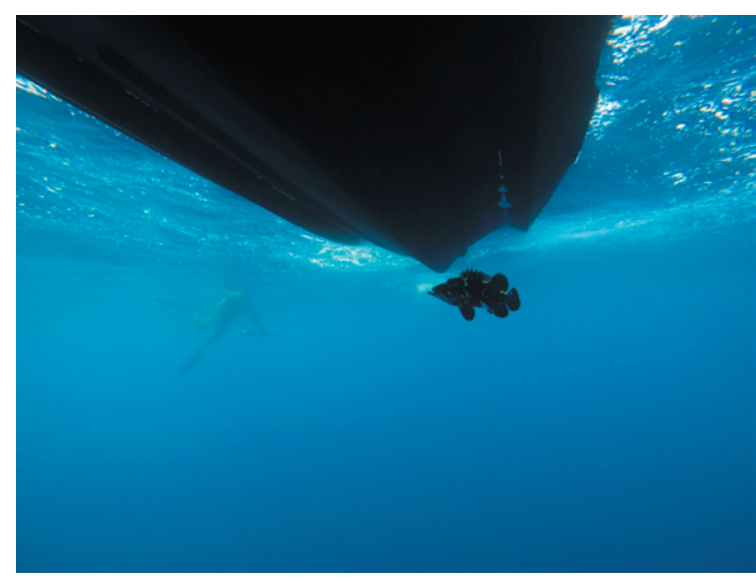

Fig. 2. Polyprion americanus beneath a boat (in Poreč 2018) (Photo: R. Basanić)

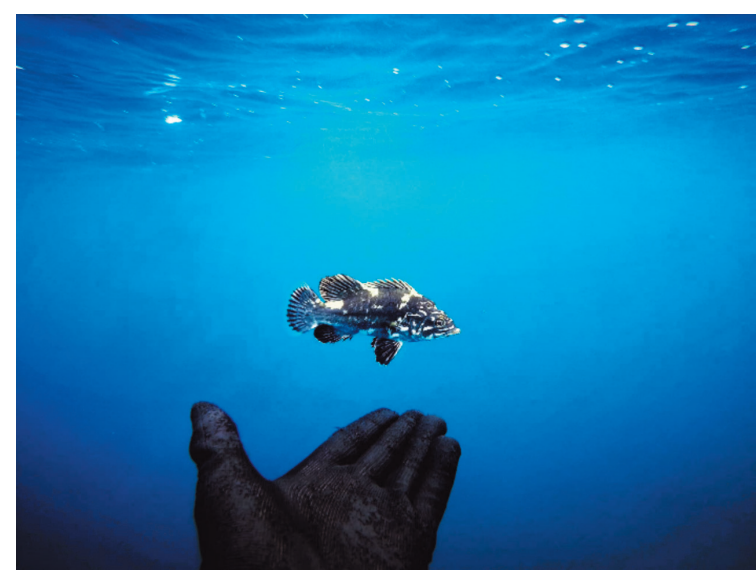

Fig. 3. Polyprion americanus in the Gulf of Trieste (June 2009) (Photo: L. Faresi) 


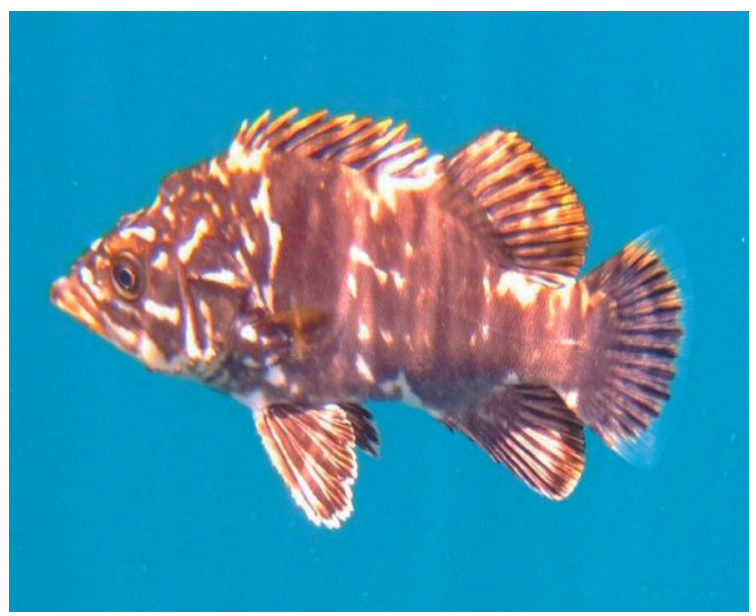

Fig. 4. An approximately $25 \mathrm{~cm}$ long specimen of the wreckfish, captured in waters off Piran at $12^{\text {th }}$ July 2014 (Photo: V. Oblak)

\section{RESULTS AND DISCUSSION}

Morphometric measurements of $P$. americanus are shown in Table 1. Pearson linear correlation coefficient (PCC) revealed a complete isomorphism among specimens (Table 2). The total length (TL) of these pelagic juveniles ranged between 15.9 to $20.3 \mathrm{~cm}$, according to the ranges recorded by LO BIANCO (1909) and KIRINČIĆ \& LEPETIĆ (1955). The stomachs were empty, only the specimen 2 showed some undetermined vegetal fragments.

Table 1. Morphometric measurements of Polyprion americanus specimens

\begin{tabular}{l|c|c|c}
\hline specimen & $\mathbf{1}$ & $\mathbf{2}$ & $\mathbf{3}$ \\
\hline TL $(\mathrm{cm})$ & 20.3 & 18.4 & 15.9 \\
\hline SL & 16.6 & 15.7 & 13.3 \\
\hline PAL & 11.4 & 11 & 9 \\
\hline PDL & 7.3 & 6.1 & 5.6 \\
\hline HL1 & 6.9 & 5.9 & 5.4 \\
\hline HL2 & 6.4 & 5.5 & 5 \\
\hline P & 2.4 & 2.3 & 2.1 \\
\hline AH & 5.6 & 5.4 & 4.9 \\
\hline SH & 6.9 & 6.2 & 5.5 \\
\hline HH & 4.4 & 3.6 & 3.2 \\
\hline E & 1.2 & 1.1 & 0.9 \\
\hline S & 1.7 & 1.5 & 1.4 \\
\hline Weight $(g)$ & 160.1 & 120.6 & 81.9 \\
\hline
\end{tabular}

Table 2. Pearson linear correlation coefficient (PCC)

\begin{tabular}{ccc}
$P C C$ & specimen 2 & specimen 3 \\
specimen 1 & 1.00 & 1.00 \\
specimen 2 & & 1.00 \\
\hline
\end{tabular}

The knowledge on the life history, as well as on the biology and ecology of this species along the Italian seas is still fragmentary and few data exist on reproductive cycle and growth (CARBONARA et al., 2003). Due to its rapid growth even at relatively low temperatures, the good adaptation to captivity, together with high flesh quality and market value, the wreckfish is an excellent candidate for the aquaculture production (PAPADAKI et al., 2018) and therefore the interest for this species is increasing. The slow reproductive maturation occurring at an age of 5-10 years in captivity, may be a problem for broodstock development and management, but its long juvenile stage represents a great advantage from the aquaculture viewpoint, allowing the commercialization before the sexual maturity, thus avoiding problems linked to maturation, such as reduction in growth (RODRíGUEZ-VILLANUEVA et al., 2017). P. americanus reaches a large size at a relatively young age (WAKEFIELD et al., 2013): a study on wild caught specimens revealed a growing from 1 to $5 \mathrm{~kg}$ in a period of 10 months (RODRÍGUEZ-VILLANUEVA et al., 2011; PÉREZ et al., 2019). MACHIAS et al. (2003) reported an increase of almost ten times in term of weight during the first year of life for individuals monitored in captivity, and with regards to the pelagic phase, fish reached their maximum observed size in 1 year; although in the wild similar lengths are not attained until 2 or 3 years of age (MACHIAS et al., 2003). In addition CARBONARA et al. (2003) reported a $15.5 \mathrm{~cm}(75 \mathrm{~g})$ wreckfish caught in the North Western Ionian Sea and maintained in captivity for 2 months, which showed an increment of $440 \%$ in term of weight. Nevertheless, the same authors recorded the youngest specimen $\left(1^{+}\right.$year old) in the demersal phase as an immature female $50 \mathrm{~cm}$ TL and $2.1 \mathrm{~kg}$ in total weight (CARBONARA et al., 2003).

Spawning of wreckfish occurs at depths ranging from 450 to $850 \mathrm{~m}$ (GLUKHOV \& ZAFERMAN, 1982; SEDBERRY et al., 1999). As reported by BROOKS \& BANE (1978) these spawning areas 
have some specific environmental conditions such as a very high pressure, an absence of light but also, in the case of South Carolina (Blake Plateau), a rocky bottom and an upwelling (PAPANDROULAKIS et al., 2004). PERES \& KLIPPEL (2003) reported that spawning occurs at the continental slope (300-500 m) for the Southwestern Atlantic wreckfish.

In the $19^{\text {th }}$ century STOSSICH (1880) and PERUGIA (1881) reported this species as very rare in the Adriatic. In particular PERUGIA (1881) referred of some specimens got from Trieste, Rijeka and Cres Island, but no other information are available about the size or the time of appearance. The Gulf of Trieste, as well as, the whole northern Adriatic Sea does not show such a depth and presumably only pelagic phase can be recorded in this basin, probably arriving from the nearest breeding areas, southern Adriatic and/or Ionian Sea. In the Gulf of Trieste BUSSANI (1974) recorded the presence of juvenile specimens (TL $14.5-19.5 \mathrm{~cm}$ ), still recognized as P. cernium, during the summer 1974. About 150-200 specimens were caught every night during the fishing of small pelagic fish (Sardina pilchardus, Engraulis encrasicolus) and mackerels (Scomber scombrus), attracted by light and captured in the purse seine. In fact, wreckfish fed avidly on Engraulis and Sardina, as observed in the gut content by BUSSANI (1974).

BUSSANI (1986) sustained that this species alternates a massive appearance in the Gulf of
Trieste after a long period of total absence. To our knowledge, in fact, we recorded its appearance in 2000 (BETTOSO, pers. observation), 2009, 2014 and finally in 2018.

Some fishermen had the experience to catch juvenile specimens of $P$. americanus in the Gulf of Trieste: a juvenile specimen was caught at the depth of $17 \mathrm{~m}$ close to the lighthouse on the promontory of Izola in 1998 (VALENČIČ, pers. comm.). By using the modern approach of Local Ecological Knowledge (see AZZURRO et al., 2011, 2019), which take into consideration local fishermen and other stakeholders as monitoring tools, the number of records would probably increase substantially. The occurrence of $P$. americanus in the Gulf of Trieste is not a typical case of thermophilic species moving northward due to Mediterranean tropicalization, rather its recurrent appearance could be investigated for specific hydrological conditions coupled to its peculiar life span. At present, we can only wait for the next appearance to confirm or not a such hypothesis.

\section{AKNOWLEDGEMENTS}

Authors would like to express their gratitude to Sergio Felluga for wreckfish specimens and to Roman Basanić, Peter Valenčič and Vinko Oblak for their help in providing photographical material.

\section{REFERENCES}

AZZURRO, E., P. MOSCHELLA \& F. MAYNOU 2011.

Tracking signals of change in Mediterranean fish: Diversity based on Local Ecological

Knowledge. PLOS, 6(9): e24885.

AZZURRO, E., P. SBRAGAGLIA, J. CERRI, M.

BARICHE, L. BOLOGNINI, J. BEN SOUSSI, G.

BUSONI, S. COCO, A. CHRYSSANTI, J. GAR-

RABOU, F. GRATI, J. KOLITARI, G. LETTERIO,

L. LIPEJ, C. MAZZOLDI, N. MILONE, F. PAN-

NACCIULLI, A. PEŠIĆ, Y. SAMUEL ROADS, L.

SAPONARI, J. TOMANIĆ, N. EDA TOPCU, G.

VARGIU \& P. MOSCHELLA 2019. The shifting distribution of Mediterranean fishes: a spatio-temporal assessment based on Local Ecological Knowledge. Global Change Biology. First published: 20 May 2019. doi:https://doi. org/10.1111/gcb.14670.

BALL, A., G. SEDBERRY, M. ZATCOFF, R. CHAPMAN \& J. CARLIN 2000. Population structure of the wreckfish Polyprion americanus determined with microsatellite genetic markers. Mar. Biol., 137(5/6): 1077-1090.

BOMBACE, G. 1972. Ittiofauna e produzione terziaria del coralligeno di substrato duro della 
costa settentrionale di Sicilia. Quad. Lab. Tecnol. Pesca, 3(1-4): 23-37.

BROOKS, D.A. \& J.M. BANE JR. 1978. Gulf stream deflection by a bottom feature off Charleston, South Carolina. Science, 201: 1225-1226.

BUSSANI, M. 1974. Polyprion cernium (Cuv. et Val.) in the Gulf of Trieste. Atti Parco Marino di Miramare, 1(9): 1-4.

BUSSANI, M. 1986. Alcune specie ittiche presenti nell'area del Parco Marino di Miramare osservate durante il decennio 1968-77. Hydrores information, 2(3): 5-94.

CARBONARA, P., G. COSTANTINO, G. GIOVINE, G. LEMBO, M.T. SPEDICATO \& A. MACHIAS 2003. Some aspects of the life history of Polyprion americanus (Schneider, 1801) along the coasts of the North western Ionian Sea. Biol. Mar. Medit., 10(2): 102-112.

CAU, A. 1980. Secondo contributo alla conoscenza dell'ittiofauna batiale dei mari circostanti la Sardegna Meridionale (Osteichthyes). Quad. Civ. Stn. Idrobiol. Milano, 8: 39-44.

FISCHER, W., M.L. BAUCHOT \& M. SCHNEIDER 1987. Fiche FAO d'identification des espèces pour les besoins de la pêche, Rev. 1. Méditerranée et Mer Noire (zone de pêche 37). FAO, Rome.

GLUKHOV, A.A. \& M.L. ZAFERMAN 1982. Observations of the behavior of Polyprion americanus (Serranidae). J. Ichthyol., 22: 142-143.

JARDAS, I., A. PALLAORO, N. VRGOČ, S. JUKIĆPELADIĆ \& V. DADIĆ 2008. Crvena knjiga morskih riba Hrvatske (The red book on Croatian marine fish). Ministarstvo Kulture, Državni zavod za zaštitu prirode. Republika Hrvatska. Pp. 1-396.

KIRINČIĆ, J. \& V. LEPETIĆ 1955. Recherches sur l'ichthyobenthos dans les profondeurs de l'Adriatique méridionale et possibilitè d'exploitation au moyen de palangres. Acta Adriat., 7: 3-113.

LO BIANCO, S. 1909. Notizie biologiche riguardanti specialmente il periodo di maturità sessuale degli animali del Golfo di Napoli. Mitth. Zool. Stat. Naples, 19(4): 513-763.

MACHIAS, A., S. SOMARAKIS, N. PAPANDROULAKIS, M.T. SPEDICATO, M. SUQUET, G. LEMBO \& P. DIVANACH 2003. Settlement of the wreck- fish (Polyprion americanus). Mar. Biol., 142: 45-52.

MARČETA, B. 1999. Osteichthyes. In: Kryštufek \& Janžekovič (Editors). Ključ za določanje vretenčarjev Slovenije. DZS, Ljubljana, pp. 47- 210.

PAPADAKI, M., J.B. PELETEIRO, B. ÁLVAREZBLÁZQUEZ, J.L. RODRÍGUEZ VILLANUEVA, F. LINARES, A. VILAR, E. PÉREZ RIAL, N. LLUCH, I. FAKRIADIS, I. SIGELAKI \& C.C. MYLONAS 2018. Description of the annual reproductive cycle of the wreckfish Polyprion americanus in captivity. Fishes, 3: 43.

PAPANDROULAKIS, N., M. SUQUET, M.T. SPEDICATO, A. MACHIAS, C. FAUVEL \& P. DIVANACH 2004. Feeding rates, growth performance and gametogenesis of wreckfish (Polyprion americanus) kept in captivity. Aquacult. Int., 12: 395-407.

PERES, M.B. \& KLIPPEL S. 2003. Reproductive biology of southwestern Atlantic wreckfish, Polyprion americanus (Teleostei: Polyprionidae). Environ. Biol. Fish., 68: 163-173.

PÉREZ, E., F. LINARES, J.L. RODRÍGUEZ VILLANUEVA, A. VILAR, C.C. MYLONAS, I. FAKRIADIS, M. PAPADAKI, N. PAPANDROULAKIS, I. PAPADAKIS, R. ROBLES, C. FAUVEL, J. ROO, J.B. PELETEIRO, N. LLUCH, G. PAZOS, B. MÉNDEZ, I. SIGELAKI, C. GÓMEZ, M. PÉREZ \& B. ÁLVAREZBLÁZQUEZ 2019. Wreckfish (Polyprion americanus). New knowledge about reproduction, larval husbandry and nutrition. Promise as a new species for aquaculture. Fishes, 4: 14.

PERUGIA, A. 1881. Elenco dei pesci dell'Adriatico. Milano U. Hoepli Editor

RODRÍGUEZ VILLANUEVA, J.L., J.B. PELETEIRO, E. PÉREZ RIAL, E.C. SOARES, B. ÁLVAREZBLÁZQUEZ, C. MARIÑO, F. LINARES \& E. MAÑANÓS 2011. Growth of wreckfish (Polyprion americanus) in Galicia, Spain. In Proceedings of the European Aquaculture 2011, Rhodes, Greece, 18-21 October 2011.

RODRÍGUEZ VILLANUEVA, J.L., B. ÁLVAREZBLÁZQUEZ, E. PÉREZ RIAL, J.M. MARTÍNEZ, G. PAZOS \& F. LINARES 2017. Evaluation of wreckfish (Polyprion americanus) growth in Galicia (Spain). In Proceedings of the European Aquaculture 2017, Dubrovnik, Croatia, 17-20 October 2017. 
SEDBERRY, G.R., C.A. ANDRADE, J.L. CARLIN, R.W. CHAPMAN, B.E. LUCKHURST, C.S. MANOOCH, G. MENEZES, B. THOMSEN \& G.F. ULRICH 1999. Wreckfish Polyprion americanus in the North Atlantic: fisheries, biology and management of a widely distributed and long-lived fish. Am. Fish. Soc. Symp., 23: 27-50.

STOSSICH, M. 1880. Prospetto della fauna del Mare Adriatico, III. Boll. Soc. adriat. sci. nat. Trieste, 6(1): 178-271.
TORTONESE, E. 1975. Fauna d'Italia. Osteichthyes, vol XI. Calderini Bologna.

WAKEFIELD, C.B., S.J. NEWMAN \& D.K. BODDINGTON 2013. Exceptional longevity, slow growth and late maturation infer high inherent vulnerability to exploitation for bass grouper Polyprion americanus (Teleostei: Polyprionidae). Aquat. Biol., 18: 161-174.

\title{
Pojava kirnje glavulje Polyprion americanus u Tršćanskom zaljevu (sjeverni Jadran)
}

\author{
Nicola BETTOSO, Lisa FARESI, Alessandro FELLUGA i Lovrenc LIPEJ \\ *Kontakt e-pošta: nicola.bettoso@arpa.fvg.it
}

\begin{abstract}
SAŽETAK
Dana 3. lipnja 2018. u Tršćanskom zaljevu ulovljena su tri jedinke mlađi kirnje glavulje Polyprion americanus. Kirnja glavulja je dugovječna vrsta duboke vode, koju karakterizira produljena pelagična faza mlađi.

Jedinke mlađi opetovano se bilježe u sjevernom Jadranu, a zbog nedostatka podataka za ovu vrstu, prikazani su izvorni morfometrijski podaci.

Pojava $P$. americanus u Tršćanskom zaljevu nije tipičan slučaj termofilnih vrsta koje se kreću prema sjeveru zbog mediteranske tropikalizacije, već bi se njihov ponovljeni nalaz mogao istražiti u specifičnim hidrološkim uvjetima zajedno s osebujnim životnim vijekom ove vrste.
\end{abstract}

Ključne riječi: Polyprion americanus, morfometrijski podaci, pelagična faza, Tršćanski zaljev, Jadransko more 